\title{
Adsorption Heavy Metal from Contaminated Water by Modified Shell of Wild Endemic Almonds: Amygdalus lycioides and Amygdalus wendelboi
}

\author{
Parisa Ziarati $^{1 *}$, Armaghan Kermanshah ${ }^{2}$ and Maryam Moslehishad ${ }^{3}$ \\ ${ }^{1}$ Depatment of Medicinal Chemistry, Pharmacy Faculty, \\ Pharmaceutical Sciences Branch, Islamic Azad University (IAUPS), Tehran, Iran. \\ ${ }^{2}$ Pharmaceutical Sciences Branch, Islamic Azad University (IAUPS), Tehran, Iran. \\ ${ }^{3}$ Young Researchers Club, Pharmaceutical Sciences Branch, \\ Islamic Azad University (IAUPS), Tehran, Iran.
}

DOI: http://dx.doi.org/10.13005/bbra/1923

(Received: 19 July 2015; accepted: 15 October 2015)

\begin{abstract}
Heavy Metals in Water resources is one of the most important environmental problems of countries. Up to now various methods of removing of these metals is considered, which is including using of low prices materials. In this study the potential of two wild endemic almond: Amygdalus lycioides and Amygdalus wendelboi shells was assessed for adsorption of heavy metal ions such as $\mathrm{Ni}^{2+}, \mathrm{Cr}^{6+}$ and $\mathrm{Cr}^{3+}$ from aqueous solution. A. lycioides and $A$. wendelboi fruits were collected in June 2013 from Sirmand Mountains near Hadji-Abad County, Hormozgan Province and the mountains in Gnow protected area, Bandar-Abbas, Hormozgan Province in Iran respectively. The analyzing for $\mathrm{Ni}$ and $\mathrm{Cr}$ (III) and $\mathrm{Cr}$ (VI) concentrations using inductively coupled plasmaatomic emission spectrometry (ICP-AES). Adsorption capacity of $\mathrm{Cr}(\mathrm{VI}), \mathrm{Cr}$ (III) and Ni onto modified almond shells by Phosphoric acid was investigated in a batch system by considering the effects of various parameters like contact time, initial concentrations, $\mathrm{pH}$ , temperature, absorbent dose and particle size. The adsorption was $\mathrm{pH}$ solution dependent and the maximum adsorption was observed at solution $\mathrm{pH}$ of 3.2. The amounts of $\mathrm{Cr}(\mathrm{VI})$ adsorbed increased significantly with increase in dose of $A$. wendelboi adsorbent $(p<0.02)$ and their contact time $(p<0.05)$. The results of this study revealed that $A$. lycioides and A. wendelboi can accumulate high level of Chrome (VI) and (III) in a short time and their uptake rate by plant is significantly affected by their concentrations in the contaminated water $(\mathrm{p}<0.005)$. A contact time of 48 by both almond shells was found to be optimum and $83.6 \% \mathrm{Cr}(\mathrm{VI}), \mathbf{9 0 . 2} \% \mathrm{Cr}(\mathrm{III})$ and $94.1 \% \mathrm{Ni}$ was removed. Experimental results show low cost biosorbent was effective for the removal of pollutants from aqueous solution.
\end{abstract}

Key words: Wild Almond, Contaminated water, Adsorbent, Removal of Heavy Metals.

Water pollution is a major global problem and it is leading worldwide cause of deaths and diseases. Pollution of the biosphere with toxic metals has accelerated dramatically since the beginning of the Industrial Revolution ${ }^{1,2}$. Wetland

\footnotetext{
* To whom all correspondence should be addressed. Tel: +98-21-22600037; Fax: +98-21-22633986; E-mail: ziarati.p@iaups.ac.ir
}

is a water environment which has considerable scientific, economical, and, social values. They are the habitats of various organisms contributing to the gene cache of microbes, plants and animals on the earth. However, nowadays the pollution and degradation of the wetlands are increasing dramatically $^{3}$. Marine animals can accumulate metals through sea water, suspended particles, sediments and food chains ${ }^{4}$. Permanent contaminants such as metals may be transferred to 
higher levels in the food chain through environmental expansion. The levels of these contaminants, due to environmental socialization of species are generally much higher in marine physico than the surroundings ${ }^{4}$. Behavior of trace elements in various weathering environments is dramatically different. In world soil neutral or alkaline weathering environments, $\mathrm{U}, \mathrm{V}, \mathrm{Mo}$, and $\mathrm{Zn}$ have high mobility, while $\mathrm{Mn}, \mathrm{Pb}, \mathrm{Ba}, \mathrm{Be}$, and Bi have low mobility, and $\mathrm{Cu}, \mathrm{Co}, \mathrm{Fe}, \mathrm{Ni}, \mathrm{Th}, \mathrm{Y}$ have very low mobility. Otherwise, in reducing environment conditions As, $\mathrm{Ba}, \mathrm{Be}, \mathrm{Bi}, \mathrm{Cd}, \mathrm{Co}, \mathrm{Cu}$, $\mathrm{Mo}, \mathrm{Ni}, \mathrm{Pb}, \mathrm{Se}, \mathrm{Th}, \mathrm{U}, \mathrm{Zn}, \mathrm{V}$, and Y have a very low degree of mobility ${ }^{5}$.

The vast industrial waste materials and sewages from a lot factories and different chemical fertilizers and pesticides in Tehran have caused contamination of soils ${ }^{6,7}$. The soil and water of other cities especially in the north of Iran has been already contaminated. Gilan Province, owing to its rich natural resources, is one of the most populated provinces in Iran ${ }^{8,9}$. Irrigated agriculture is one of the most well-known causes of groundwater contamination throughout the Gilan state (south Caspian Area) in the north of Iran. According to the provincial statistics in 1998, Rasht City 1.4 million $\mathrm{m}^{3}$ untreated sewage into the river which is attributed to the increasing urban development ${ }^{10}$. There are more than 30 main polluted factories in Gilan $^{11,12}$. Among these industries, Wood and Paper Company in Talesh, Wood Fiber Company in Hassan Rood, Iran Poplin textile, Gilan Carpet, Pars Khazar house ware, Zam-Zam soft drink, and several food industries in Rasht are important to mention. The lack of proper wastewater treatment plant in some of these companies will add pollution to the rivers that will end to the Wetland. Department of Environment (DOE) has established standards and regulations for discharging pollution to the environment ${ }^{13,14}$. Although, lots of effort has been applied so far to implement the DOE's laws and regulations in all activities of I. R. Iran including industries, hospitals and trade centers, but lots of works need to be done to secure the job. It has been shown that the most polluting sources are from industries.

The concentrations of pollutants in textile wastewaters vary according to the wastewater management practices and their dilution after production. Textile dyes are one of the most prevalent types of chemicals in use today. Around 10000 different dyes with an annual production of more than $7 \times 105$ metric tons worldwide are commercially available. Heavy metals are the most dangerous type of chemical pollutants since they cause serious health hazard. In India, about 200032000 tons of elemental Metal (Cr) annually escapes into the environment ${ }^{15,16}$. The other heavy metal which is a major concern in this study is Nickel. Vesali-Naseh et al in 2012 had a research study on the Heavy metal concentrations and magnetic susceptibility of sediment samples which were analyzed as indicators of urban and industrial contamination in Anzali wetland in Gilan, Iran. They reported that the average value of $\mathrm{Ni}$ concentration was above SEL $(50 \mathrm{mg} / \mathrm{kg})$ at all cores. Concentration of Ni was higher than the values of other lakes and This fact could be related to the industrialization and urbanization of the wetland basin ${ }^{17}$. Heavy metal contamination in aquatic ecosystems due to discharge of industrial effluents may pose a serious threat to human health. Alkaline precipitation, ion exchange columns, electrochemical removal, filtration, and membrane technologies are the currently available technologies for heavy metal removal ${ }^{18}$. The conventional technologies are not economical and may produce adverse impacts on aquatic ecosystems. Phytoremediation of metals is a costeffective "green" technology based on the use of specially selected metal-accumulating plants to remove toxic metals from soils and water. Plants are ideal agents for soil and water remediation because of their unique genetic, biochemical and physiological features ${ }^{19,20}$. The various methods of removal of $\mathrm{Cr}(\mathrm{VI})$ from industrial wastewater include filtration, chemical precipitation, adsorption, electrodeposition and membrane systems, or even ion exchange process. Chemical precipitation and reduction process needs other separation techniques for the treatment and disposal of high quantities of waste metal residual sludge produced. These techniques use various treatment chemicals and the residual $\mathrm{Cr}(\mathrm{VI})$ concentration required in the treated wastewater is not achieved because of the structure of the precipitates. The application of membrane systems for the wastewater treatment has major problems like membrane scaling, fouling and blocking. The drawback of the ion exchange process is the high 
cost of the resin, while the electrodeposition method is more energy intensive than other methods. Among these methods adsorption is one of the most economically favorable, as well as being a technically easy method ${ }^{9}$. Considerable attention has been devoted to the study of removal of heavy metal ions from solution by adsorption using agricultural materials such as waste wool, nut wastes, tree bark, modified cotton and sawdust ${ }^{10-}$ ${ }^{21}$. Many agricultural byproducts such as almond and other fruit or nut shells. As Iran is one of the richest countries in the world as regards genetic resources of medicinal and wild unknown plants that some of them are export ${ }^{22}$. We have studied on potential ability of Amygdalus specie as this endemic specie found in some parts of Iran especially in south regions due to accumulate Chrome and Nickel as the major concern in wetland pollution.

Almond (Rosaceae family) with wide applications in pharmaceutical, oleo chemicals, food and cosmetic industries is considered as a pleasant nut throughout the world. Other than the regular almond, there are more than thirty wild or partially cultivated almond species in the world of which twenty species have been reported in Iran ${ }^{1,}$ 23. Amygdalus wendelboi is an endemic species distributed just in south of Iran, in Mountains of Gnow protected area ${ }^{4}$. The fruits locally called "Archen", has a wide application in folk medicine to treat cold, cough, headache and skin burns. Amygdalus lycioides locally called "Badamak" is one of the endemic species found in some parts of Iran especially in south regions ${ }^{4}$. It is traditionally used as antidiabet ${ }^{5}$ antiinflammation, antibacterial and laxative agent ${ }^{6}$. After removing the bitterness from the kernel oil, it could be used as edible nutritive oil. Several studies have been reported on A. lycioides different parts. Phenolic and flavonoid contents of this plant determined as 233 and $13.4 \mathrm{mg} / \mathrm{g}^{7}$. These are locally used as edible kernels by people. Literature survey revealed that no investigation has been done on the potential of adsorbing heavy metals by these species by now. The objective of this research was investigation of the potential of the Amygdalus lycioides and Amygdalus wendelboi high-biomass as hyperaccumulator to phytoextract $\mathrm{Cr}$ and $\mathrm{Ni}$ from artificial metalliferous media .

\section{MATERIALSAND METHODS}

\section{Study of Area}

A. lycioides and $A$. wendelboi fruits and their shells were collected in June 2013 from Sirmand mountains near Hadji-Abad County, Hormozgan Province and the mountains in Gnow protected area, Bandar-Abbas, Hormozgan province respectively. Both samples were identified by R. Asadpour. The Geno Biosphere Reserve, with a total area of 27,500 hectares, situated in the Hormozgan province of Iran. It has been designated as a protected area by the Iranian Department of Environment in 1976. The area is mountainous region that located among plains and hills. The region's geographical location "18 27 to" $29^{\circ} 27$ north latitude and " $18^{\circ} 56$ to" $56^{\circ} 55^{\prime}$ 'east longitude, is located in the north of Bandar Abbas ( figure 1). Plain part of the region includes much of the southern, eastern and northern part of the strip consisted of alkaline and saline soils contain large amounts of soluble salts such as chloride, sulfate and carbonate of $\mathrm{Ca}, \mathrm{Mg}$, sodium, and potassium ${ }^{23,24}$.

Shell samples were washed several times with deionized water and dried (sun or mechanical). The adsorbents were then ground in a blender and stored for further use. All reagents and chemicals were used of analytical reagent grade and were obtained from standard sources.

Phosphoric acid, Activated carbon, Potassium dichromate and other chemicals were obtained from standard sources.

\section{Experimental design and Chemical analysis}

Cr was introduced independently at two speciation as $\mathrm{Cr}(\mathrm{III})$ and $\mathrm{Cr}(\mathrm{VI})$, known for their diverse physicochemical properties and different influence on living organisms. Nutrient solution was supplied to the plants daily, starting one week after transplanting. The composition of the nutrient solution was $0.5 \mathrm{mM} \mathrm{Ca}\left(\mathrm{NO}_{3}\right)_{2}, 3.1 \mathrm{mM} \mathrm{NH}_{4} \mathrm{NO}_{3}$, $0.01 \mathrm{mM} \mathrm{KH}_{2} \mathrm{PO}_{4}, 50.0 \mu \mathrm{M} \mathrm{KCl}, 0.2 \mu \mathrm{M} \mathrm{CuSO}_{4}$, $2.0 \mu \mathrm{M} \mathrm{MnSO}_{4} \cdot \mathrm{H}_{2} \mathrm{O}, 0.5 \mu \mathrm{MZnSO}_{4} \cdot 7 \mathrm{H}_{2} \mathrm{O}$, and 0.2 $\mathrm{mM} \mathrm{MgSO}$. The almonds sell treatment groups were supplied with 100, 200 and $300 \mathrm{ppm}$ Nickel in the form of $\mathrm{Ni}\left(\mathrm{NO}_{3}\right)$; and 100,200, $300 \mathrm{ppm}(\mathrm{Cr}(\mathrm{VI})$, and $600 \mathrm{ppm}(\mathrm{Cr}(\mathrm{VI})$, chromium in the form of $\mathrm{K}_{2} \mathrm{Cr}_{2} \mathrm{O}_{7}$ and the same concentration of $\mathrm{Cr}$ (III) too in the form of $\mathrm{CrCl}_{3}$. Cr was introduced 
independently at two speciation as $\mathrm{Cr}$ (III) and $\mathrm{Cr}$ (VI), known for their diverse physicochemical properties and different influence on living organisms.

The shell parts of A. lycioides and A. wendelboi were soaked in phosphoric acid $2 \%$ for 60 hours and then dried at $80^{\circ} \mathrm{C}$ in an oven for 24 hours. Dry parts were then ground and weighed. Shell samples (approximately $0.5 \mathrm{~g}$ ) were digested with concentrated $\mathrm{HNO}_{3}$ and $\mathrm{H}_{2} \mathrm{O}_{2}$ [6,7, 25-29 ]. The digested solution was filtered and then analyzed for Ni and Cr (III) and Cr (VI), concentration using inductively coupled plasmaatomic emission spectrometry (ICP-AES).

\section{Statistical Method}

One-parametric Kruskal-Wallis/MannWhitney $U$ tests were applied to compare differences between objects. Non-parametric multiple comparison test (Dunn's test) was performed to determine statistical significance of results at $\alpha=0.05$. The GLM procedure was used for analysis of different metal treatments with means separated by Duncan's multiple range test at $p<0.05$. The CORR procedure was used for correlation analysis with means separated at $p<0.05$.

\section{RESULTS}

\section{Chemical analysis}

Experimental results showed that the percentage removal $\mathrm{Cr}$ (VI) increases with the increasing amount of adsorbent up to $5.4 \mathrm{~g}$ for treated shells by phosphoric acid $2 \%$. After this dose of adsorbent no significant change was observed, but for untreated almond shells percentage removal $\mathrm{Cr}$ (VI) increases with the

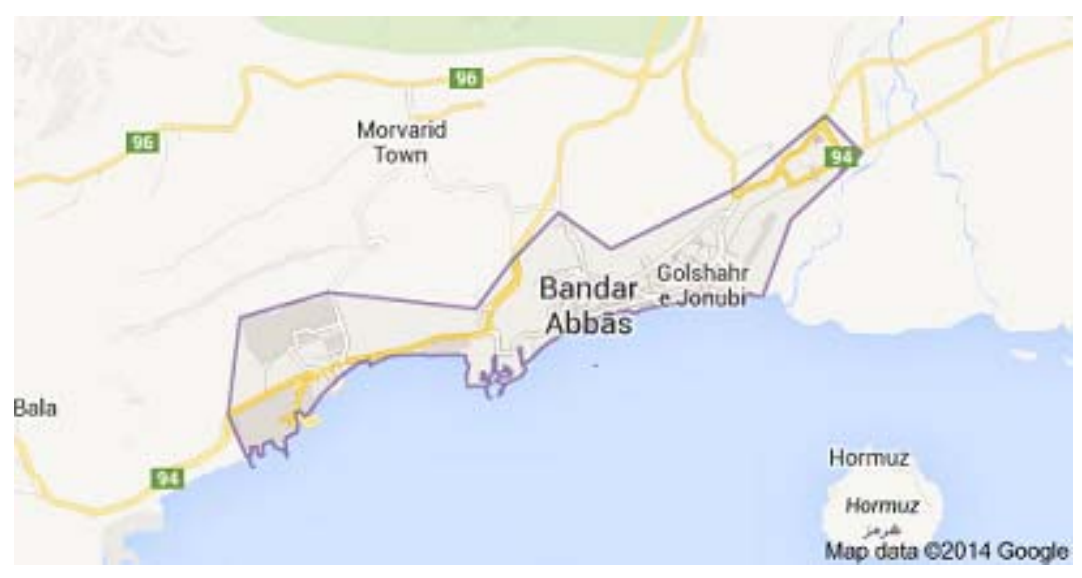

Fig. 1. Location of A. lycioides and A.wendelboi samples collection

increasing amount of adsorbent .

Metal accumulation in shells increased significantly with an increase in applied metal solution concentration in both Nickel (figure 2) and $\mathrm{Cr}$ (III) and $\mathrm{Cr}(\mathrm{VI})$, (figures 3 and 4 respectively ) treated groups. In figures 2,3 and 4 the mean contents of heavy metals are reported. The metal concentrations remained high in shells in Cr (III) and $\mathrm{Cr}(\mathrm{VI})$, treated groups, while Ni metal content was higher in treated shells than untreated shells . The ratios of shells/water ratios were calculated to indicate the translocation efficiency of $\mathrm{Ni}$ and $\mathrm{Cr}$ from water to the adsorbents. The $\mathrm{Cr}$ (III) concentrations in samples after 10, 20, 30 and 40 hours are higher in shells than $\mathrm{Cr}(\mathrm{VI})$, hence the translocation factor ratios were less than one for $\mathrm{Cr}$ ( VI) treated samples shows that this method is highly suitable for adsorbing $\mathrm{Cr}(\mathrm{III})$ to the $\mathrm{Cr}$ (VI) . Even though the $\mathrm{Cr}(\mathrm{VI})$, concentration of shells of Cr treated samples in 50 hours treated samples is higher compared to controls solutions, the extent of metal accumulation and uptake efficiency of $\mathrm{Cr}(\mathrm{III})$ was lower than that of $\mathrm{Cr}(\mathrm{VI})$, in long term contaminated situation study. Most of shells in $\mathrm{Cr}$ (VI) samples deformed after 60 hours remaining in contaminated water. The effect of adsorbent dose on $\mathrm{Cr}$ (VI) uptake was investigated by varying the shell adsorbent dose (1, 2, 3, 4 and $6 \mathrm{~g} / 100 \mathrm{ml})$ for a time interval of 0-60 hours min (Fig-4). 


\section{DISCUSSION}

The results of present study revealed that

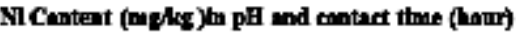

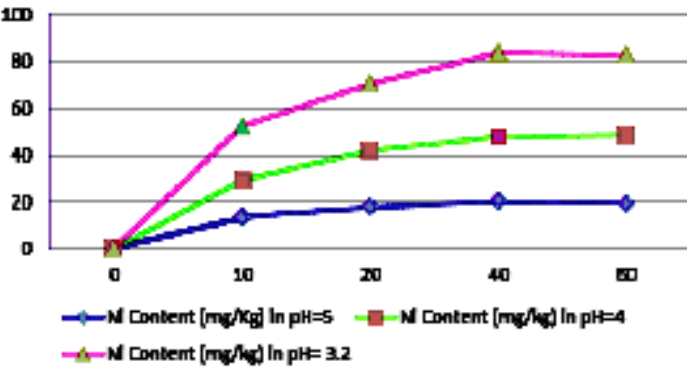

Fig. 2. The mean content of Nickel ( $\mathrm{mg} / \mathrm{kg}$ ) in A. lycioides and $A$. wendelboi treatment groups in contaminated 100, 200 and 300 ppm Nickel solution in the form of $\mathrm{Ni}\left(\mathrm{NO}_{3}\right)$ in different pHs and contact times (hours)

CrIII)Content (nejes ) in pH and contact time (bour)

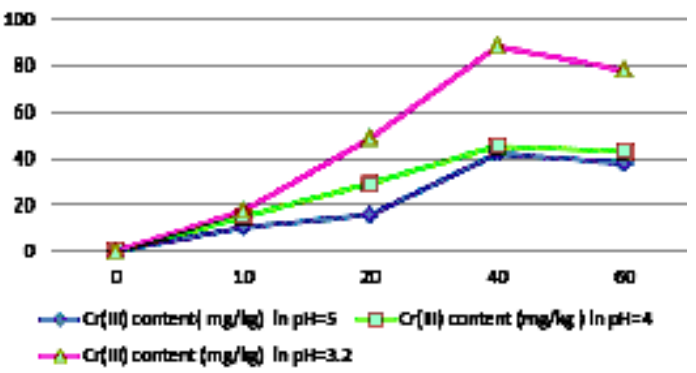

Fig. 3. The mean content of $\mathrm{Cr}(\mathrm{III})(\mathrm{mg} / \mathrm{kg})$ in A. lycioides and $A$. wendelboi treatment groups in contaminated 100, 200 and 300 ppm Nickel solution in the form of $\mathrm{Ni}\left(\mathrm{NO}_{3}\right)$ in different pHs and contact times (hours)

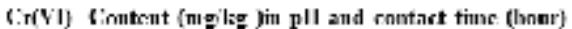

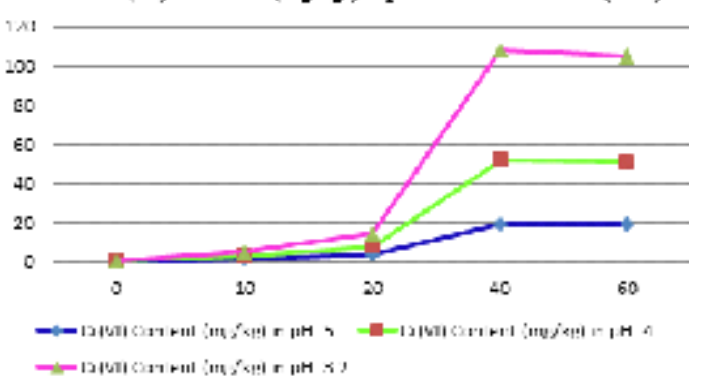

Fig. 4. The mean content of $\mathrm{Cr}(\mathrm{VI})(\mathrm{mg} / \mathrm{kg})$ in $A$. lycioides and $A$. wendelboi treatment groups in contaminated 100, 200 and 300 ppm Nickel solution in the form of $\mathrm{Ni}\left(\mathrm{NO}_{3}\right)$ in different $\mathrm{pHs}$ and contact times (hours) adsorption potential in contaminated water solutions was $\mathrm{pH}$ dependent and the maximum adsorption was observed at solution $\mathrm{pH}$ of 3.2. The amounts of Cr (VI) adsorbed increased significantly with increase in dose of $A$. wendelboi adsorbent $(p<0.02)$ and their contact time $(p<0.05)$. A contact time of 48 was found to be optimum and 83.6\% Cr(VI), 90.2\% Cr(III)and 94.1\% Ni was removed. Experimental results show low cost biosorbent was effective for the removal of pollutants from aqueous solution.

According to ATSDR, current evidences indicate that $\mathrm{Cr}(\mathrm{VI})$ is a cancer agent only by inhalation. Chronic inhalation studies on mice exposed to airborne $\mathrm{Cr}$ (VI) suggest that $\mathrm{Cr}(\mathrm{VI})$ is an animal carcinogen ${ }^{39}$. The mice developed lung tumors from exposure to $4.3 \mathrm{mg} / \mathrm{m} 3$ of $\mathrm{Cr}(\mathrm{VI})$.However, a number of chronic animal studies showed no carcinogenic effects in rats, rabbits, or guinea pigs exposed to $1.6 \mathrm{mg} / \mathrm{m} 3$ of $\mathrm{Cr}(\mathrm{VI})^{7,31-33}$. Thus, cancer effects on animals seem to depend on the type of animal. Eating small amounts of chromium (VI) is not harmful. However, eating or drinking large amounts in food or water can cause an upset stomach, ulcers, convulsions, and damage the kidneys and liver. This type of exposure can be fatal. There is not enough data to know if eating or drinking chromium (VI) causes cancer ${ }^{32}$. The results of this study revealed that $A$. lycioides and $A$. wendelboi can accumulate high level of Chrome (VI) and (III) in a short time and their uptake rate by plant is significantly affected by their concentrations in the contaminated water $(\mathrm{p}<0.005)$. The amount of Cr deposited in leaves in both Crtreated plants differed significantly $(\mathrm{p}<0.02)$. As expected the heavy metals uptake rate by this plant is significantly affected by the weight and concentration of shells specially by $A$. wendelboi as for Nickel uptake $(\mathrm{p}<0.03)$ while for chrome the $p$-value was less than 0.01 . The results of this research concluded that $A$. wendelboi in the contaminated water had more suitable ability than A. lycioides for adsorbing heavy metals by method and transmitting more Chrome and Nickel in $\mathrm{pH} \leq$ 3 after 48 hours of contacting time. The accumulation of all studied metals against singleelement substrates indicate that the bioaccumulation coefficient increases as total metal concentrations increase. In fact, the highest efficiency of $\mathrm{Cr}$ accumulation by almond shells was 
occurred when the water was contaminated by 600 $\mathrm{mg} / \mathrm{kg}$ of $\mathrm{Cr}$ (III) and also Cr (VI). The following conclusions are made based on the results of the present study and scientific information derived from literature:

The present investigation shows that the almond shells are effective and inexpensive biosorbents for the removal of $\mathrm{Cr}$ (VI) from aqueous solutions.; The removal of $\mathrm{Cr}(\mathrm{VI})$ from aqueous solutions strongly depends on the contact time, initial concentration, $\mathrm{pH}$, temperature, agitation speed, absorbent dose and particle size.; The amounts of $\mathrm{Cr}(\mathrm{VI})$ adsorbed increased with an increase in dose of both adsorbents and their contact time. A contact time of 48 hours was found to be optimum. ; The maximum adsorption capacity was obtained at solution $\mathrm{pH}$ of 3.2.

Also, this research suggests more investigations by other genera and families of cheap waste agricultural products applying as adsorbents for these heavy metals and other toxic metals such as Lead, cadmium, arsenic and Mercury.

\section{ACKNOWLEDGEMENTS}

Financial Supports from Pharmaceutical Sciences Branch, Islamic Azad University (IAUPS) is gratefully acknowledged.

\section{REFERENCES}

1. Nriagu , J.O. Global inventory of natural and anthropogenic emission of trace metals to the atmosphere. Nature J., 1979; 279: 409-411.

2. Sayyed, M.R.G, Sayadi, M.H. Variations in the heavy metal accumulations within the surface soils from the Chitgar industrial area of Tehran. Proceedings of the International Academy of Ecology and Environmental Sciences, 2011; 1(1): 36-46.

3. Dadgar, S., Teimoori, B., Yousefi, S., Tabatabaei, MDetermination of PCB levels in skin and muscle of northern pike (Esox lucius) in Anzali Wetland, Iran. Annals of Biological Research ., 2014; 5(1):112-117. Available in site: http:// www.scholarsresearchlibrary.com.

4. Saghali, M., Baqraf, R., NejatkhahManavi, P., Abbas Hosseini, S., Patymar, R. Assignment of Concentration of Heavy Metals (Cr, Zn, Cd, $\mathrm{Pb}$ ) In Sediments of Gorgan Bay and South East the Caspian Sea (Golestan Province- Iran)2010-
2011. Environment and Ecology Research., 2013; 1(2): 27-31. Available in Site: http:// www.hrpub.org/download/201309/eer.2013. 010201.pdf.

5. H. Abbaslou, F. Martin, A. Abtahi , F. Moore . Trace element concentrations and background values in the arid soils of Hormozgan Province of southern Iran, Archives of Agronomy and Soil Science, 2014; 60(8): 1125-1143. Available online: http://dx.doi.org/10.1080/03650340. 2013.864387).

6. Ziarati, P., Alaedini, S. The Phytoremediation Technique for Cleaning up Contaminated Soil By Amaranthus sp. J Environ Anal Toxicol. , 2014; 4: 208. doi: 10.4172/2161-0525.1000208.

7. Ziarati, P., Iranzad-Asl, S. ,Asgarpanah, J. Companion Pelargonium Roseum and Rosmarinus Officinalis in Cleaning Up Contaminated Soil by Phytoextraction Technique the Role of Companion Plants in Boosting Phytoremediation Potential International Journal of Plant, Animal and Environmental Sciences. 2014; 4(3) : 424-430.

8. Charkhabi AH , Sakizadeh M and Rafiee G. Seasonal Fluctuation in Heavy Metal Pollution in Iran’s Siahroud River. Environ Sci \& Pollut Res ., 2005;1: 1-7.

9. Seifi-Nigje Gheshlagh, F., Ziarati, P., Arbabi Bidgoli, S. Seasonal Fluctuation of Heavy Metal and Nitrate Pollution in ground water of Farmlands in Talesh Gilan,Iran. International Journal of Farming and Allied Sciences. ,2013; 2(20): 836-841.

10. Shirinfekr A .2001.Investigation of heavy metal levels in Siahroud River and their accumulations in soil and rice of irrigated paddy fields. M.Sc dissertation. University of Tehran, Iran.

11. Hamshahri Newsletter, September 7, 2003.

12. Ayati. B. Investigation of Sanitary and Industrial Wastewater Effects on Anzali Reserved Wetland. Presented to MAB - UNESCO . 2003. Available in Site: http://www.unesco.org/mab/doc/mys/ 2002/ayati/ayati.pdf .

13. Tashayoie, H. R., Ghannadi, M., Elahi Nia, N., Boronz, A. R., Khalili, M., "Water and Wastewater Industry of Iran, Water and Wastewater Company” (Persain), 1999.

14. Industrial and Mineral Gilan State’s Guidebook, "Industrial and Mines Organization in Gilan Province”, 2001.

15. Barnhart J., "Occurrences, uses, and properties of chromium”. Regul Toxicol Pharm 1997; 26: S3-7.

16. Rizwana, M., Darshan ,M. Nilesh, D. Phytoremediation of Textile Waste Water Using 
Potential Wetland Plant: Eco Sustainable Approach. International Journal of Interdisciplinary and Multidisciplinary Studies (IJIMS), 2014; 1(4): 130-138. Available online at http://www.ijims.com .

17. Vesali Naseh, M. R., Karbassi, A., Ghazaban, F., Baghvand, A., Mohammadizadeh, M.J. Magnetic susceptibility as a proxy to heavy metal content in the sediments of Anzali wetland, Iran. Iranian Journal of Environmental Health Science and Engineering . 2012; 9: 34. doi:10.1186/1735-2746-9-34.

18. Rai, P.K. Heavy metal pollution in aquatic ecosystems and its phytoremediation using wetland plants: an ecosustainable approach. Int. J. Phytoremediation., 2008; 10(2):131-58.

19. Ahmadi, M., Ziarati ,P., Manshadi,M., Asgarpanah, J., Mousavi, Z. The Phytoremidiation Technique for Cleaning up Contaminated Soil by Geranium (pelargonium roseum). Intl. J. Farm \& Alli. Sci.,2013; 2(15): 477-481.

20. Brix, H. The Use of Macrophytes in Waterpollution Control. Ambio. ,1989; 18(2): 100107.

21. Schnoor, J.L. Phytoremediation . Technology Evaluation Report. Te,98-01, Ground Water Remediation Technology Analysis Center , Concurrent Technologies Crop. Pittsburg, Pennsylvania 1997; pp 37.

22. Yousefia, M., Olyaei Juybari, E., Yahyapor, M.K., Dehpour, A. A. , Hoseinzade, M. Brine Shrimp Lethality Activity of land and fresh water Medicinal Plants. Advances in Environmental Biology,. 2012; 6(3): 1196-1199.

23. Kermanshah, A., Ziarati,P., Asgarpanah,J., Qomi, M. Food values of two endemic wild almond species from Iran. International Journal of Plant, Animal and Environmental Sciences., 2014; 4(3): 380-388.

24. Li, Y.M., Chaney, R.L., Brewer, E.P., Angle, J.S., Nelkin, J. Phytoextraction of nickel and cobalt by hyperaccumulator Alyssum species grown on nickel-contaminated soils. Environ Sci Technol., 2003; 37:1463-1468.

25. Balaji, B. Maruthi Sridhar' F., Han X., Diehl, V.
S., Monts, D., L. ,Yi Su . Effect of Phytoaccumulation of Arsenic and Chromium on Structural and Ultrastructural Changes of Brake Fern (Pteris vittata). Braz. J. Plant Physiol. ,2011; 23 (4) .Available in Site: http:/ /dx.doi.org/10.1590/.

26. Han, F.X. and Banin, A. Long-term transformations and redistribution of potentially toxic heavy metals in arid zone soils. I. under saturated conditions. Water Air Soil Pollut. 1997; 95: 399-423.

27. Jackson, M.L. Soil chemical analysis. Prentice Hall, New Jersey. 1958.

28. Sridhar, B.B.M., Han, F.X., Diehl, S.V., Monts, D.L., Su, Y Effects of Zn and Cd accumulation on structural and physiological characteristics of barley plants. Braz. J. Plant Physiol, 2007a; 19: 15-22.

29. Sridhar, B.B.M, Han, F.X, Diehl, S.V, Monts, D.L, Su, Y. Monitoring the effects of Arsenicand Chromium- accumulation in Chinese brake fern (Pteris vittata) using microscopy and near infrared spectral reflectance. Int. J. of Remote Sens. , 2007b; 28: 1055-1067.

30. Ziarati P, Ziarati N. N, Nazeri S, Saber-Germi M. Phytoextraction of Heavy Metals by two Sorghum Spices in Treated Soil "Using Black Tea Residue for Cleaning-Uo the Contaminated Soil”. Orient J Chem 2015; 31(1): 317-326. Available from: http://www.orientjchem.org/ ?p=7693.

31. Guertin ,J. Toxicity and Health Effects of Chromium (All Oxidation States). L1608_C06.fm. 2004; Pp: 213 . Available in site : http://www.engr.uconn.edu/ baholmen/ docs/ENVE290W/National \% 20 Chromium \% 20 Files \% 20 From \% 20 Luke / Cr (VI)\% 20Handbook/L1608_C06.pdf .

32. http://www.eco-usa.net/toxics/chromium.shtml. 33. Ahmadi, M., Ziarati, P., M. Manshadi, Asgarpanah, J. ,Mousavi, Z.. The Phytoremidiation Technique for Cleaning Up Contaminated Soil by Geranium (pelargonium roseum). International Journal of Farming and Allied Sciences. 2013;2(15): 477-481. Available online: www.ijfas.com . 